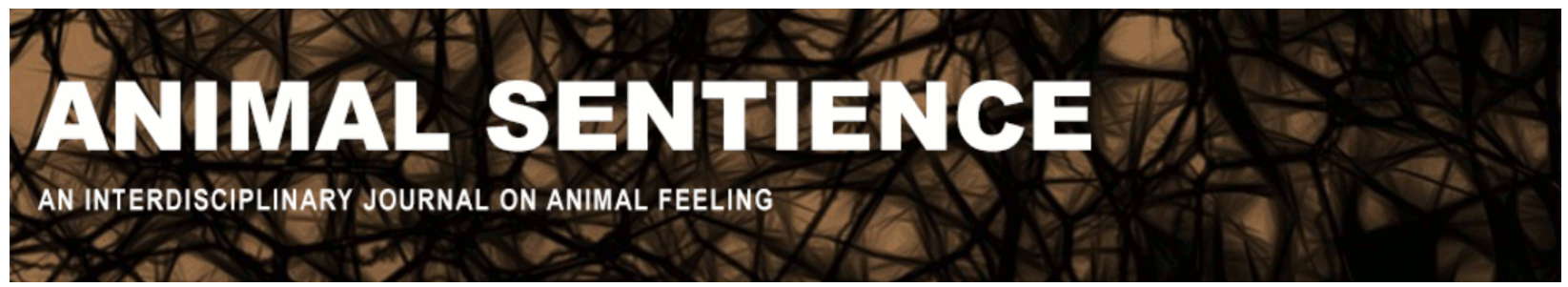

Figdor, Carrie (2020) Relationship between cognition and moral status needs overhaul. Animal Sentience 29(3)

DOI: $10.51291 / 2377-7478.1584$

Date of submission: $2020-06-10$

Date of acceptance: 2020-06-14 (c) 


\title{
Relationship between cognition and moral status needs overhaul
}

Commentary on Mikhalevich \& Powell on Invertebrate Minds

\author{
Carrie Figdor \\ Department of Philosophy and Department of Psychological and Brain Sciences \\ University of lowa
}

\begin{abstract}
I commend Mikhalevich \& Powell for extending the discussion of cognition and its relation to moral status with their well researched and argued target article on invertebrate cognition. I have two small criticisms: that the scala naturae still retains its appeal to some in biology as well as psychology, and that drawing the line at invertebrates requires a bit more defense given the larger comparative cognitive-scientific context.
\end{abstract}

Carrie Figdor, Professor of Philosophy, University of lowa does research on theoretical issues in the foundations of psychology. She is the author of Pieces of mind: The proper domain of psychological predicates by Oxford University Press (2018). Website

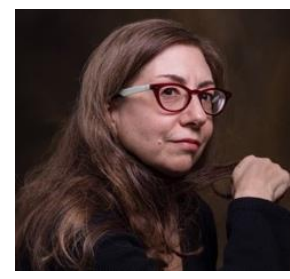

It is gratifying to see Mikhalevich \& Powell's (2020) (M\&P) further exploration of the moral consequences of taking seriously the ascription of mind to a wider variety of nonhuman species. If we take these ascriptions literally, as I advocate (Figdor 2018), a clear implication is that the traditional grounds of moral status in psychological traits needs to be reconsidered. This includes - for basic moral consideration - having conscious experience (in particular, the capacity to suffer) and - for full moral status - having cognitive capacities, a category currently exclusive to humans (Jaworska and Tannenbaum 2018).

In "The Psychological Speciesism of Humanism" (forthcoming), I focus on this relationship between psychological traits and moral status, arguing that the acknowledgement of the evolved nature of minds precludes using the human mind as the cognitive standard, and consequently, as the moral standard. Both are built into the scala naturae, which orders the species by a scale of perfection leading to God. This cognitive and moral hierarchy is already rejected in evolution, is being rejected in the foundations of comparative psychology, and remains to be rejected in ethics. What is needed instead is a conception of moral status that puts treatment before status. The only reason we care about moral standing is the differences in treatment that the differences in status represent. So why not just start from the perspective of justification for systematically different treatment? This starting point is species-neutral in that the relevant statuses can crosscut species lines, and it unbundles moral status in that there could be a systematic justification for worse treatment in one respect and better treatment in another respect. For example, perhaps no treatment differential is justifiable when it comes to suffering: all beings that can suffer have equal consideration. But (assuming appropriate limitations) perhaps one group that might justifiably be experimented on might not justifiably be killed, whereas another group that 
might justifiably be killed might not be justifiably experimented on. The groups may or may not align with species.

Where I would disagree with M\&P's otherwise commendable discussion is that it is not the case that biology has "long jettisoned progressivist readings of evolutionary history." On the contrary, even in biology, the scala naturae way of thinking about comparative biology is found in neuroscience (Cesario et al. 2020; Marino 2003; Parvizi 2009). It has proved to be incredibly difficult to stop thinking of $H$. sapiens as the end or "apex" of evolution (e.g., Dobzhansky 1973; Chapman \& Huffman 2018). With respect to insects in particular, Dennett's (1973) famous and repeated example of the Sphex wasp - characterized as an inflexible machine incapable of any learning - is as clear an example of confirmation bias as one might want; Keijzer (2012) makes clear just how biased it is.

Another smallish point of disagreement is that perhaps M\&P don't go far enough in their critique. The range of creatures that some thinkers have claimed to have some psychological traits includes not just those without vertebrae, but also those without brains, including bacteria and plants (Lyon 2015; Reber 2016; Calvo 2017) - i.e., not just animals, but living things in general. M\&P acknowledge this wider perspective only to set it aside. But if we are reconsidering the grounds of moral status and the role of cognition in establishing those grounds, why it is that invertebrates should be the appropriate contrast group - why M\&P draw the line where they do - needs a bit of defense in light of these contemporary discussions.

\section{References}

Calvo, P. (2017) What is it like to be a plant? Journal of Consciousness Studies 24 (9-10): 205-227.

Cesario, J., D. Johnson, \& Eisthen, H. (2020) Your brain is not an onion with a tiny reptile inside. Current Directions in Psychological Science 29 (3): 255-260.

Chapman, C. A., \& Huffman, M. A. (2018) Why do we want to think humans are different? Animal Sentience 23(1).

Dennett, D. (1973) Mechanism and responsibility. In T. Honderich (ed.), Essays on Freedom of Action (London: Routledge): 159-184.

Dobzhansky, T. (1973) Nothing in biology makes sense except in the light of evolution. The American Biology Teacher 35 (3): 125-129.

Figdor, C. (2018) Pieces of mind: The proper domain of psychological predicates (Oxford University Press). Figdor, C. (forthcoming) The psychological speciesism of Humanism. Philosophical Studies.

Jaworska, A., \& Tannenbaum, J. (2018) The grounds of moral status. In E. Zalta (ed.), The Stanford Encyclopedia of Philosophy.

Keijzer, F. (2012) The Sphex story: How the cognitive sciences keep repeating an old and questionable anecdote. Philosophical Psychology 26 (4): 502-519.

Lyon, P. (2015) The cognitive cell: Bacterial behavior reconsidered. Frontiers in Microbiology 6 (264): 118.

Marino, L. (2003) Has scala naturae thinking come between neuropsychology and comparative neuroscience? International Journal of Comparative Psychology 16: 28-32.

Mikhalevich, I., \& Powell, R. (2020) Minds without spines: Evolutionarily inclusive animal ethics. Animal Sentience 29(1).

Parvizi, J. (2009) Corticocentric myopia: Old bias in new cognitive sciences. Trends in Cognitive Sciences 13 (8): 354-359.

Reber, A. S. (2016) Caterpillars, consciousness and the origins of mind. Animal Sentience 11(1). 


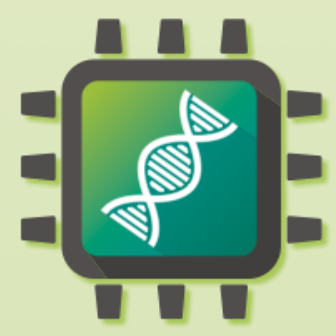

\section{Summer School 2020}

INNOVATIVE SCIENCE WITHOUT ANIMALS

June 22-26, 2020

\section{Online Virtual Conference}

\section{Calling all students and early-career researchers!}

Join us for a FREE conference on innovative approaches in toxicology and biomedical sciences!

\section{This event features:}

- Lecture sessions about modern alternatives to the use of animals in toxicology and biomedical sciences

Virtual laboratory tours

E-poster presentations

Virtual engagement with speakers and attendees

Deadline to apply for the full program is June 10. Registration for individual lectures is available.

For more information visit InnovativeScience2020.org

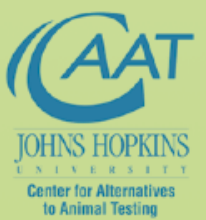

Physicians

committee

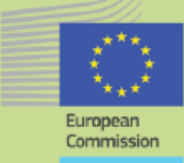

